\title{
Cerebellar atrophy in neuroacanthocytosis
}

\author{
Chandramohan Sharma, ${ }_{1}^{1}$ Kunal Nath, ${ }^{2}$ Mihir Acharya, ${ }^{2}$ Banshi Lal Kumawat, ${ }^{1}$ \\ Dinesh Khandelwal, ${ }^{1}$ Deepak Jain ${ }^{1}$
}

${ }^{1}$ Department of Neurology, Sawai Mansingh Medical College and Hospital, Jaipur, Rajasthan, India ${ }^{2}$ SMS Medical College, Jaipur, Rajasthan, India

Correspondence to Professor Chandramohan Sharma,

cmsharma65@hotmail.com

Accepted 18 May 2014

\section{DESCRIPTION}

We present the case of a 25 -year-old man who had progressive generalised choreoathetosis, orofacial dyskinesia, feeding dystonia (jaw closure dystonia), lip biting and cervical dystonia (retrocollis) for the past 2 years. Over the past 6 months he has also had truncal and gait ataxia. He had a history of behaviour changes in the form of psychosis and obsessive compulsive disorder 2 years prior to the onset of chorea. There was no family history of similar symptoms.

Examination revealed normal fundus with no evidence of retinitis pigmentosa and proximal weakness of grade 4/5 Medical Research Council in the upper and lower limbs. The reflexes in lower limbs were absent. Sensory examination was normal. Cardiac examination was normal.

The peripheral blood film, prepared by diluting with normal saline (to increase the 'echinocytotic stress'), showed $15 \%$ of red blood cells as acanthocytes. The complete blood count, liver function tests, renal function tests, serum lipids, lipid electrophoresis, serum ceruloplasmin, $24 \mathrm{~h}$ urinary copper, serum ammonia, urine for organic acids, thyroid profile, erythrocyte sedimentation rate and serum b12 levels were all within normal limits. Creatine phosphokinase levels were elevated $(400 \mathrm{u} / \mathrm{L})$. Two-dimensional echocardiography and ECG were normal. The nerve conduction study revealed pure motor axonopathy and the electromyography (EMG) showed a neurogenic pattern.

A brain MRI (figure 1) revealed atrophy of the head of caudate bilaterally and diffuse cerebellar atrophy.
The following differentials were discussed:

1. Chorea-acanthocytosis (ChAc)

2. McLeod neuroacanthocytosis syndrome (MLS)

3. Abetalipoproteinaemia (Bassen-Kornzweig syndrome)

4. HARP (hypoprebetalipoproteinemia, acanthocytosis, retinitis pigmentosa and pallidal degeneration)

5. Huntington's disease (HD)/Huntington's diseaselike 2 (HDL2)

6. Pantothenate kinase-associated neurodegeneration (PKAN)

7. Wilson's disease

The presence of chorea and athetosis has never been described in abetalipoproteinaemia. Also patients with abetalipoproteinaemia have a history of frequent loose stools and early onset sensory ataxia and retinitis pigmentosa, all of which were absent in our patient. The serum lipid profile of the patient was normal and serum lipid electrophoresis was also normal, also ruling out this possibility.

Similarly the normal lipid profile and absence of reinitis pigmentosa ruled out the possibility of HARP.

Although HD is the most common cause of degenerative chorea, the absence of family history of similar symptoms was against the diagnosis of $\mathrm{HD}$. The test for the huntingtin $(\mathrm{Htt})$ gene on chromosome 4 p16.3 revealed 22 CAG repeats, which is normal, ruling out the possibility of HD.

HDL2 can have acanthocytes in $10 \%$ of patients, but the presence of arreflexia, raised levels of creatine kinase and presence of task-specific feeding dystonia made a strong point against this diagnosis.

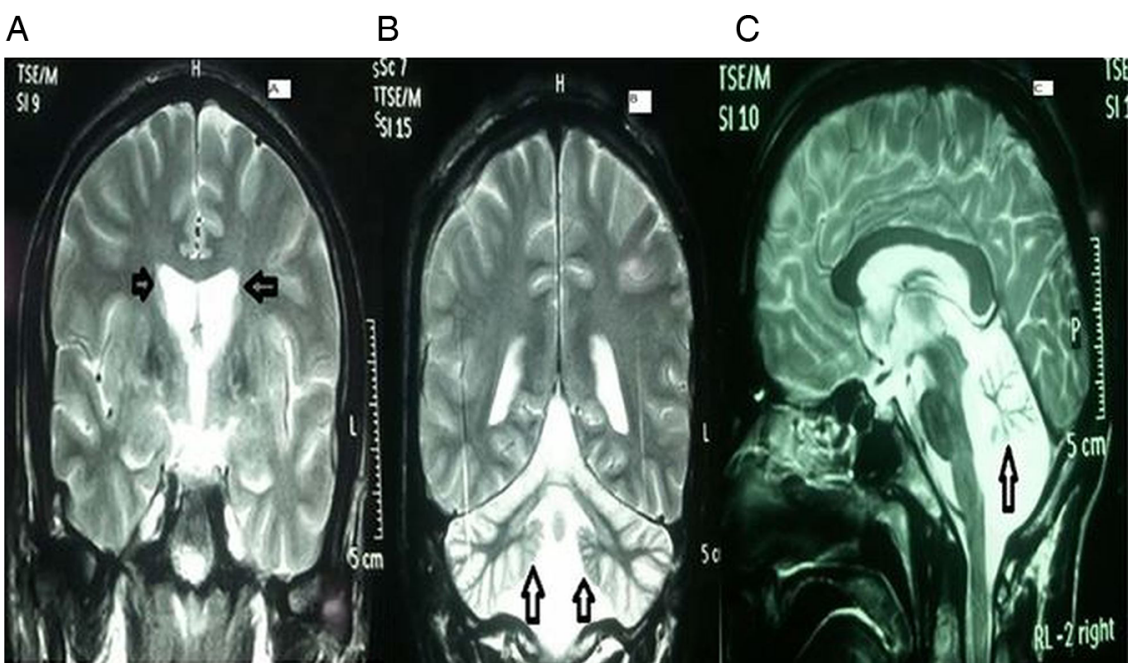

Figure $1 \mathrm{MRI}$ of the brain showing ( $\mathrm{A}$; coronal section) atrophy of head of caudate (arrows); ( $\mathrm{B}$; coronal section) diffuse cerebellar atrophy (arrows) and ( $C$; sagittal section) marked cerebellar atrophy (arrows). 
Patients with PKAN do have lingual dystonias, but taskspecific feeding dystonias are not present in them. The absence of pigmentary retinopathy and the absence of the typical 'eye of tiger sign' on T2-weighted MRI ruled out the possibility of PKAN.

Wilson's disease was ruled out on the basis of absent Kayser-Fleischer ring, normal serum ceruloplasmin and $24 \mathrm{~h}$ urinary copper.

The only two differentials left were ChAc and MLS.

The presence of task-specific feeding dystonia, involuntary tongue and lip biting, absence of cardiomyopathy, onset of disease in the second decade and presence of $15 \%$ acanthocytes on peripheral blood film strongly favoured the diagnosis of ChAc over MLS.

Since the confirmatory DNA analysis of the large vacuolar protein sorting 13A gene (for ChAc) is difficult due to the large gene size, heterogeneity of mutations and non-availability at our centre, this test could not be carried out.

However by extensively ruling out all the close differential diagnoses in a stepwise manner the diagnosis of ChAc was entertained.

The patient was put on tetrabenazine and trihexyphenidyl and has shown significant improvement in chorea and dystonia.

Neuroacanthocytosis (NA) syndromes are a group of genetically defined diseases characterised by the association of red blood cell acanthocytosis and progressive degeneration of the basal ganglia. ${ }^{1}$

NA syndromes were known initially under the eponym 'Levine-Critchley syndrome'. Patients described by Critchley were clinically compatible with ChAc and the genetic analysis of the family described by him support this fact. However the detailed genetic analysis of the family described by Levine could not be made as it was lost in follow-up. ${ }^{1}$

The NA syndromes have been further divided into 'Core' NA syndromes which include ChAc and MLS; and NA with lipoprotein disorders which include abetalipoproteinaemia (BassenKornzweig syndrome). ${ }^{1}$

The chief presenting features of ChAc are chorea, orofacial dyskinesias, lingual and feeding dystonia and self-mutilation. ${ }^{2}$

The imaging findings of ChAc consist of bilateral caudate atrophy with or without T2 hyperintensity in putamen. ${ }^{2}$ Cerebellar atrophy has been very rarely described in $\mathrm{ChAc}^{2}$ and diffuse cerebellar atrophy has probably never been described in the literature.
Voxel-based morphometry of MRI of the brain showed specific atrophy of the head of caudate nucleus with sparing of the rest of the cerebral cortex in patients with ChAc. ${ }^{1}$

Functional imaging may be helpful in diagnosis of ChAc. Single photon emission CT may show frontal hypoperfusion. Fluorodeoxyglucose-positron emission tomography may show decreased striatal glucose utilisation. ${ }^{3}$

ChAc cannot be distinguished from HD solely on the basis of neuroimaging. The presence of cerebellar atrophy on neuroimaging $^{2}$ can help differentiate ChAc from HD as both may have a very similar clinical profile.

\section{Learning points}

- Diffuse cerebellar atrophy has been rarely described in chorea-acanthocytosis (ChAc).

- Presence of cerebellar atrophy may be an important radiological clue to differentiate between Huntington's disease and ChAc.

- The presence of orofacial dyskinesias, chorea, feeding dystonia, self-mutilating behaviour along with imaging evidence of caudate and cerebellar atrophy helps narrow the differential diagnosis to $\mathrm{ChAc}$.

Contributors All the authors contributed to the planning, conduct and reporting of the work described in the article and are justifiably credited with authorship, according to the authorship criteria. All the authors read and approved the final manuscript. CMS is the guarantor for the submitted manuscript.

\section{Competing interests None.}

Patient consent Obtained.

Provenance and peer review Not commissioned; externally peer reviewed.

\section{REFERENCES}

1 Jung HH, Danek A, Walker RH. Neuroacanthocytosis syndromes. Orphanet J Rare Dis 2011;6:68

2 Katsube T, Shimono T, Ashikaga R, et al. Demonstration of cerebellar atrophy in neuroacanthocytosis of 2 siblings. AJNR Am J Neuroradiol 2009;30:386-8.

3 Oechsner $\mathrm{M}$, Buchert $\mathrm{R}$, Beyer $\mathrm{W}$, et al. Reduction of striatal glucose metabolism in McLeod choreoacanthocytosis. J Neurol Neurosurg Psychiatry 2001;70:517-20.

\footnotetext{
Copyright 2014 BMJ Publishing Group. All rights reserved. For permission to reuse any of this content visit http://group.bmj.com/group/rights-licensing/permissions.

BMJ Case Report Fellows may re-use this article for personal use and teaching without any further permission.

Become a Fellow of BMJ Case Reports today and you can:

- Submit as many cases as you like

- Enjoy fast sympathetic peer review and rapid publication of accepted articles

- Access all the published articles

- Re-use any of the published material for personal use and teaching without further permission

For information on Institutional Fellowships contact consortiasales@bmjgroup.com

Visit casereports.bmj.com for more articles like this and to become a Fellow
} 